\title{
スポーツ施設サービス業におけるプロダクトの構造に関する研究
}

\author{
仲 澤 葚 ${ }^{11}$
}

\section{A study on the structure of products of commercial sports facilities}

\author{
Makoto Nakazawa ${ }^{1}$
}

\begin{abstract}
In recent Japanese sports market, the maturation is in progress. Accordingly, the service industry for commercial sports facilities has grown up remarkably.

The concept of the service industry has much influence on the future of the appreciation of commercial sports facilites.

It is not certain that the present concept being beginner oriented will be available in the future. The purpose of this study is to consider what the product of the commercial sports facility will be. P.Kotler's theory of structured product considers the sport and the need for the product.

Two groups, the committed sportsman and the beginner, were formed which differ substantially in the level of appreciation of the aport. The need for each structured product was compared with each other by way of a written questionnaire. The main results were as folows:

1) The committed sportsman has a much larger need for the core product.

2) There is no difference of needs within two groups for augmented product and formal product.

It was suggested that the various needs were changing to the essential attractive needs of sports, from the point of view that the commited sportsman's needs have been changed from the beginner's one.

It is necessary to keep up with the need for augmented product and formal product as a strategy for attracting new customers. However, when implementing this strategy the core product should not be overlooked. The long-term success of a sports facility cannot be expected if the need for the core product does not satisfy the customer who has changed from being a beginner to a dedicated sportsman. Therefore, if there is no need for the core product, the customer's involvement in the sport will be short-lived.

Catering to all needs for sports services will not be enough to produce a high level of appreciation of the sport and long-term success. In this context, the concept of the product should be developed to help customers become aware of the essential value of sports.
\end{abstract}

$$
\text { (Japan J.Sports Indus.,1 : 23-36,March,1991.) }
$$

1)帝京大学

干192-03 八王子市大塚359
1.Teikyo University,

359 Otsuka Hachioji-shi,Tokyo.(192-03) 


\section{緒文}

わが国において，スポーツが産業として形を 見せ始めたのは, 明治末期頃, 運動具の国産化 が行われてからのことである. 昭和に入り，製 造・卸・小売の三層が明確になると「産業」と しての体制が整いはじめる.

戦後の復興と東京五輪を契機としたスポーツ の大衆化から, 昭和 30 年代はスポーツ人口が急 増し, 昭和 40 年代半ばにはスポーツ産業も高度 成長時代を迎えた。経済成長が鈍化した昭和 50 年代に入っても, 健康スポーツの需要からスポ ーツ産業は成長を続けた。

しかし，50年代中ごろには，供給過㮃の様相 が見えだし，人々のライフスタイルの多様化の 影響もうけて, スポーツ市場は急速に成熟して いく．これまでのメーカー主導からユーザー主 導の産業にシフトしはじめたのである.

50 年代後半には，スポーツ産業は成熟期を迎 え, その中で施設業・サービス業関連が脚光を 浴び,これらがスポーツ産業全体の活性化へ重 要な役割を果たすようになってきている.7)

現在, スポーツ産業は4.3兆円(広義には6.4兆 円）の市場規模を持ち, 前年比伸び率は全体で 10\%前後という成長を続けている。 また, 西暦 2000 年には,それが14.8兆円(広義には22.3兆円)
になるとみられる. ${ }^{16)}$ 中でも前述のスポーツ施設 業・サービス業の領域の伸びは近年著しく, 前 年比伸び率で $15.0 \%$ を示している. ${ }^{23)}$

そして，このスポーツ施設サービス業は「ス ポーツの享受の仕方」に大きく関わる業域だけ に，そこでのプロダクトのコンセプトはスポー ツ産業界全体の将来に深く関わってくると思わ れる.

また，市場の成熟化とも関連するが，現在， スポーツ産業は, 享受のあり方やその質を問題 とする, いわゆる「文化の産業化」というテー マに対応する時期にきていると思われる. 文化 の産業化には，消費のステージが生産活動をリ 一ドする一方で, 企業もその文化の文化性と公 益性を保護・促進していく過程があり, ${ }^{11)}$ 消費者 の多様なニーズに対応することは重要なことで あるが,いたずらにあらゆるニーズに迎合せず， むしろ消費者のニーズを「享受のあり方」に照 らして, 開発し, よりょい方向へ導く側面も求 められるのである. また,これをその産業の社 会的な承認や産業の永続的な発展につなぐこと がよりよい文化産業のあり方であろう.

Fig.1は, これを図示したものであるが, 企業 は消費者から導かれる側面がある一方で, 消費 者を質の高い享受へとリードしていく側面があ

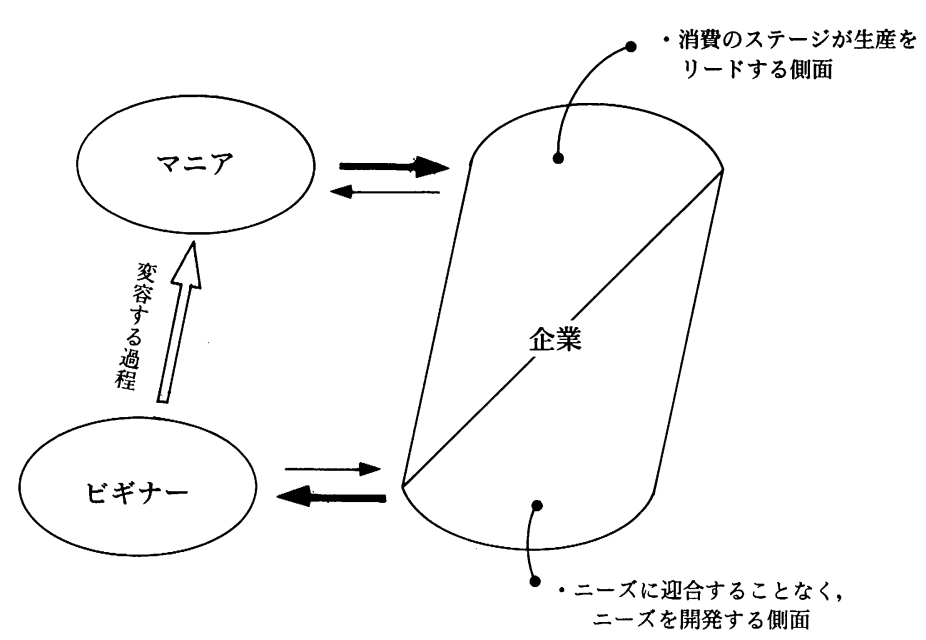

Fig.1 スポーツ産業に関わる消费者と企業の関係 (矢印の太さは与える影響の大きさと関係させて図示した) 


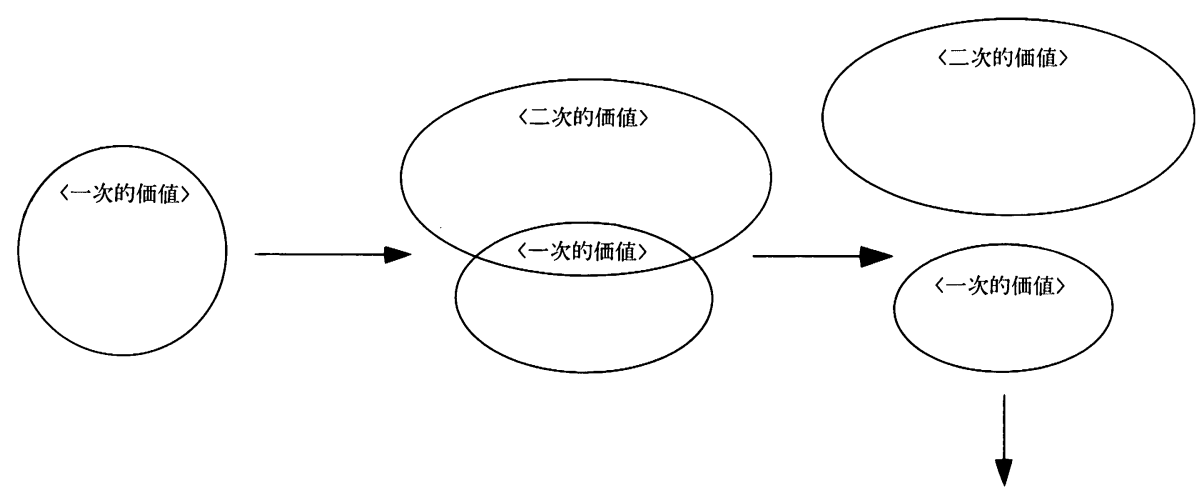

スポーツとその経営の逆機能

経営体の社会的責任

事業の社会的性格と承認

Fig.2 体育・スポーツ夷業をめぐる付加価值創造の流れ（柳沢）

ることを示したものである．概して言えば，消 費のステージが生産をリードする側面では,「マ ニアの消費者」の企業への影響が強く, ニーズ に迎合するのではなくニーズを開発する側面で は, 企業からの「ビギナーの消費者」への影響 が強い, と考えられる.しかしながら，そうし た影響のサイクルがいつもあるわけではなく， ビギナーのニーズのみで展開するプロダクトの コンセプトが一過性の流行（ブーム）を生んで いることもしばしばである.

これに関連して,体育・スポーツ経営の現状か ら, 柳沢18) は以下のような指摘をしている. (Fig. 2)

それは,「体育・スポーツ経営が生み出す付加 価值を，スポーツの一次的便益（スポーツの楽 しさや身体的効果などのスポーツの持つ本質的 価値）と二次的便益（施設の雾囲気や接客の良 さなどの周辺的・情緒的価值)で理解すれば, 従来は前者のみで営まれていたが, 商品化が進 む過程, あるいは施設競合が進む過程で後者の 創造が重要になってくる.そして，さらにエス カレートした場合, スポーツとは離れたところ で二次的便益が存在する可能性が出てくる.こ の段階では, 体育・スポーツ経営に期待される
本来の機能を十分に発揮できず，利用者との摩 擦が生じ, 経営の社会的責任論に発展する可能 性がある.利用者は様々なニーズを持っており, その対応が経営の存続に重要であることは理解 できるが，今後，経営や事業のコンセプトづく り, あるいは経営体の資質の検討が要求される ようになろう」とし, 経営の逆機能の問題を指 摘したものである.

実状としても，施設サービス利用者にはこれ まで運動にあまり親しまなかった人の占める割 合が比較的高いこと, ${ }^{14)}$ また, 近年広がりを見せ た業域からか, 会員歴の短い人の占める割合が 高いこと, ${ }^{15)}$ がある.

これらのいわばビギナーがマニアになる過程 で,「ホンモノに気づいた時に, やめていく」と いうパターンがあるならば, その永続的な発展 は望めない。もっとも，極端な例では入会金の 関係から収益目標のために意図的に，退会率を コントロールする施設もあるやにきく.しかし, これは例外であり, スポーツという文化を産業 化したものとは，ほど遠いものになってしまう であろう。

現在の需要を一過性のものに終わらせず，利 用者がスポーツとの付き合いを深め, 享受の質 
を高めていく過程でのニーズの変容を見越した プロダクトを提示していく必要があろう.

筆者は，アメリカにおけるスポーツ・マネジ メントにおいても経営関連諸科学からのアプロ 一チが目立ち,「スポーツのコンセプト」からの 展開に乏しいと感じている，それは，ビジネス が先にたち, そこでのスポーツの内容, 享受の 仕方の検討に乏しいように見受けられる。

その動向は,わが国においても同様であるが, 欧米に比べ,一般的に人々の享受レベルが高く ないであろう事情を考えれば，事態はさらに深 刻であると思われる。

スポーツ経営とは, 企業の論理と享受者（こ の場合，運動者）の論理が，享受の質的水準の 向上へ向けて統合されたものであるべきであり， それが「文化を産業化する」ことの鍵になると 考えられる. 文化の産業化のモデルとしての役 割を「スポーツ産業」が果たしていく可能性に 期待したい.

\section{I . 研究の目的}

本論は，前述のような経営の逆機能の問題， さらには，あるべきスポーツ施設サービスを検 討するために，スポーツ施設サービス業におけ るプロダクトの構造に着目し，それを利用者の スポーツの享受レベルというセグメントから分 析するものである.

そこで本研究は, 享受レベルと求められるプ ロダクトの構成の関係を明らかにし, 享受レべ ルの変容を見越したプロダクトのあり方，スポ ーツサービスのあり方を検討することを目的と する.

\section{II. 研究の方法}

\section{1. 手続き}

分析データ（注 1 ）は，以下の調査設計を持 つ質問紙調查を用いて収集した。ここで，調査 対象をスポーツ施設サービス利用者（スポーツ クラブ会員など）に限定せず，広く一般からと った背景には，そうしたサービスへアクセスし ない人を含む多様な活動形態ならびに享受レべ
ルの調査対象を求めたいという意図があった。

また，回収結果は以下のとおりである。

(1)調査設計

(1)調査対象 : 都内(島部を除く)在住の $18 \sim 65$ 歳の男女個人

(2)サンプル数 : 1000

(3)抽出方法：住民基本台帳に基づく層化二段 無作為抽出法

(4)調查方法：調查員による個別訪問留置法

(5)調査時期：平成 2 年 2 月 26 日～ 3 月 16 日 (2)回収結果

(1)回収数（率)：796(79.6\%)

(2)欠票数（率)：204(20.4\%)

（注 2 ）

\section{2. 概念と操作化}

(1)スポーツ施設サービス業

スポーツ施設サービス業は，いわゆるスポー ツクラブやスイミングクラブのように施設利用 やインストラクト事業，クラブサービスなどの スポーツ事業をサービスの中心とする業種を意 味し，施設の所有を前提としないスポーツスク 一ル業，派遣指導業とは異なるものである.

(2)スポーツのプロダクト

まず,プロダクト(Product)とは「親切, 獲得, 利用，あるいは欲求または必要を充足する消費 に向けて市場に提供される一切のものをいう。 それは物体，サービス，人々，場所，組織，そ してアイディアを含んでいる」10)(P.Kotler)とさ れ，訳語としては「製品」があてられるのが一 般的である.

商品と訳される場合も多いように，これと近 い意味内容を持つ概念として「商品」があり， それは狭義には「交換価值を有することと，商 売売買の目的物であることの両条件を保持する

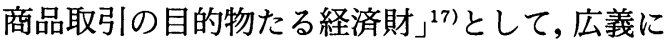
は「市場の内外における交換対象（売買客体, 交易・配給・分配の目的物）としての，有形・ 無形の存在のすべて」3)とされている.

このプロダクトとは，アメリカのマーケティ ング論においては商品の概念を包合し，ドイッ の伝統的な商品観が物質中心に展開されるのに 対し，中核思想を背景にもつ概念である，中核 
思想とは，プロダクトの中心には，その核とな る無形で触知不能な便益やサービスがあり，そ の中心は決して物体ではないという考え方で, 物質論を基礎とする伝統的な商品論とは異なり, 欲求論を中心にした特徴を持つ。そして「満足 の束」(W.Zikmund \& M.D'Amico)や「諸属 性の束」(W.F.Schoell), と言われるようにニー ズや欲求を充足するための有形・無形の便益の セットとして理解されている. 22

ここでは，スポーツに関わる「プロダクト」 と「商品」について，「スポーツのプロダクト」 を，経営体の客観的なアウトプットとして「ス ポーツに関わるニーズや欲求を充足するために 用意された有形・無形の便益のセット」とし, 便益の提供による経済的効果の有無は問わない ものとして理解し,「スポーツの商品」を, この プロダクトに市場での経済的交換を前提として 提供されるという条件が付与されたもの，(上述 の狭義の商品）として理解した. ${ }^{19)}$

本論の分析の対象は, 民間のスポーツサービ ス業におけるプロダクトであるため, 商品とし て把握するのも妥当であるように思われるが, 実際には民間でも公共でもスポーツサービス事 業は展開されており，本論の知見が民間の領域 にのみ有効であるとは考えにくい. 重要なこと は, 利用者に魅力があり, 将来的な展望をもっ た（利用者を質的にリードアップする）スポー ツサービスを考えることにあるので，特にスポ ーツの商品に限定する必要はないと考えられ, 本論では，広義にプロダクトのレベルで検討す る.

(3)スポーツ施設サービス業におけるプロダクト の構造

スポーツ施設サービス業におけるプロダクト

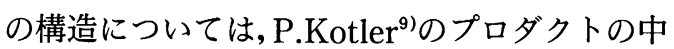
核思想に依拠した。

P.Kotlerは，プロダクトの中心には「無形の 触知できない便益, サービスがあり, 決して物 体ではない」とし，それを中核プロダクト(Core Product）とした。 そして, その中核プロダクト を規定または制約する条件が加わって正式なプ
ロダクト (Formal Product) となり, その正式 なプロダクトを獲得することにおいて受容され， 経験される便益の総体を拡延されたプロダクト

(Augmented Product) とした. ${ }^{10)}$

これをスポーツサービス業におけるプロダク トとして考えれば，まず，スポーツの持つ便益 や機能 (スポーツ活動の主観的な意味や価值) が中核的プロダクトに，中核的プロダクトを規 定または制約する条件（具体的なエリアサービ ス，プログラムサービス，クラブサービスや指 導者や職員といった人的条件など）が加わって 正式なプロダクトに，中核的プロダクトとは直 接結合しないが, 利用者の必要な欲求を充足さ せる付加価值的プロダクトが拡延的プロダクト になると考えられる. 20)2111

これに沿えば，スポーツ施設サービス業にお けるプロダクトの構造は, およそ以下のように 理解できる.

(1)中核的プロダクト

中核的プロダクトとは，スポーツの効用や便 益であり, 行う者にとっての主観的な意味や価 值を内容としている.この把握については, 運 動・スポーツの欲求階層論ならびにスポーツ観 の類型論に依拠した。まず，スポーツの意味や 価値について，スポーツを手段論的に理解した ものか，あるいは目的論的に理解したものか, という視点で検討し ${ }^{12)}$, その内容は生理的欲求, 社会的欲求, 自己実現的欲求, という三つの段 階を対応させた。そして，手段的なものに生理 的欲求と社会的欲求の内容を, 目的論的なもの に自己実現的欲求の内容を対応させた. (注 3$)^{6 / 8)}$

(2)構造的プロダクト

構造的プロダクトとは, 上記のスポーツの便 益を実現するために直接に関わる物的，人的， 諸条件を含んだ具体的なサービスであり，エリ アサービス，プログラムサービス，クラブサー ビス, 指導者の指導能力や魅力, 立地・アクセ ス条件, 利用料の条件, などから理解すること が出来る. P.Kotlerによれば, この層のプロダ クトは可視的なものとして客観的に把握され， 正式なプロダクトを成立させるものとして考察 
されているが，本論では，中核的プロダクトを 構造的に成り立たせるために必要なものとして, 構造的プロダクトと称する. ${ }^{20) 21)}$

(3)拡延的プロダクト

拡延的プロダクトは, 直接, スポーツ活動に は関係しないが, スポーツサービス業の利用者 の必要や欲求を充足し, そこでのプロダクトに 付加価値を与えるものである.
これには, 託児機能やサロン的空間などの付 帯的なエリアサービス, 職員の応対や全体的な 雲囲気といったアメニティーの問題, サービス 施設の記号的な意味（ステイタスやネームバリ ユーによる満足), 音楽や芸術などスポーツ以外 の文化との融合, など多様な内容が含まれる.

以上から作成されたものがFig.3のスポーツ施 設サービスのプロダクト構造である.（注 4 ）

拡延的プロダクト

〈アメニティー〉

・くつろげるスペースや施設がある

・おしゃれな雲囲気がある

・個人でも入りやすい雾囲気がある

・水や緑が豊富である
〈付帯的エリアサービス〉

・食堂やレストランがある

・託児施設がある

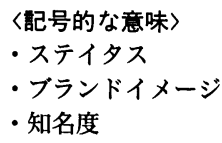

\section{楼造的プロダクト}

〈エリアサービス〉

・施設全体が清潔に保たれている

・安全面への配慮が行き届いている

・いつもすいていて使いやすい

・利用方法・手続きが簡単である

・朝早くから夜遅くまで利用できる

・個人利用の時間帯が十分にある

・シャワーの温水化など快適性への配慮がある

・どんな活動ができるのかよくわかる

・スポーツ事故等への補償が充実している

・施設・設備がよく整備されている
〈プログラムサーピス〉

・必要に応じて健康相談・チェックが受けられる

・やりたい活動が出来る

・豊富なプログラムがある

・必要なときに指導者のアドバイスを受けられる

・子どもから高齢者まで楽しめる

〈クラブサーヒス〉

・ともにスポーツを楽しむメンバーがいる

・個人種目以外にも参加できる

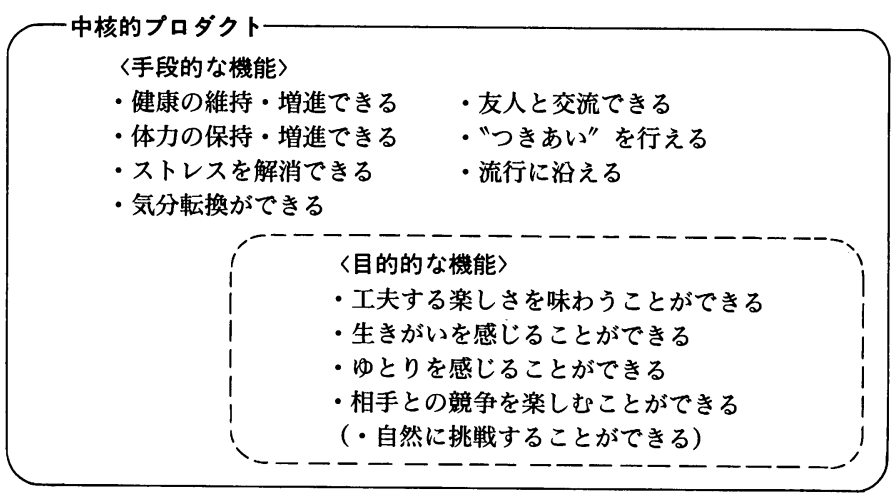

〈指筧者〉

・指導者の指導能力が優れている

・指導者が量的に充実している

・アルバイトの指導者が少ない

・指導者の態度やマナーがよい
〈立地・アクセス・利用料〉

・立地条件が行きやすい場所にある

・駐車場が十分, 確保されている

・利用料金が手軽である

〈する以外のスポーツ〉

・スポーツに関する文献や暳物を閲覧できる

〈接客〉

〈他の文化との融合〉

・スポーツ以外の文化活動が楽しめる

・スポーツ以外の文化活動の成果を発表できる
・指導者以外の職貝の態度やサービスがよい 〈利用者首〉

・他の利用者の䨌囲気がよい

Fig.3 スポーツ施設サービス業におけるプロダクトの權造 
(4)享受レベル

スポーツの享受レベルについては，スポーツ 観などの問題を含み，一概に序列化して検討す ることは困難である．また，そうした操作化は 「文化」という基本的な性格からも危険性をは らんでくる.

同様に「あるべき享受の仕方＝享受モデル」 を提示し，それに沿って検討するというアプロ 一チも，今日までの関連諸科学の成果からは困 難であると考えられた。

そこで本分析にあたっては，まず享受の前提 となると思われる「どの程度, 生活化している か」といった現在のスポーツの実施頻度と,「ど の程度，熱中した経験を持つか」という過去の スポーツへの傾倒度から享受レベルの指標とし ての合成変数を作成し，マニア群とビギナー群 という 2 つの群を形成した。（注 5 ）

Table.1は, 群形成時の各セルの分布状況を示 したものである. 享受レベルを，この 2 つの変 数が代表するか, という妥当性については, 諸々 の問題点もあろうが, 前述のビギナーの享受者 とマニアの享受者を比較検討するという観点か らは，有効であると判断した。

Table.1 享受レベルの群形成時の各セル分布状況

\begin{tabular}{|c|c|c|c|}
\hline $\begin{array}{c}\text { 過去の } \\
\text { 傾倒度 } \\
\text { 頻度 }\end{array}$ & 高傾倒群 & 低傾倒群 & \\
\hline 高頻度群 & $\begin{array}{c}101 \\
31.5 \%\end{array}$ & $\begin{array}{c}65 \\
20.3 \%\end{array}$ & 166 \\
\hline 低頻度群 & $\begin{array}{c}97 \% \\
30.2 \%\end{array}$ & $\begin{array}{c}58 \\
18.1 \%\end{array}$ & 155 \\
\hline & 198 & 123 & 321 \\
\hline
\end{tabular}

※回収総サンプル数は796であるが, 欠損值等の関係 でここでの有効サンプル数は 321 とった．表中の 網掛部分, 左上が「マニア群」, 右下が「ビギナー群」 である。

\section{III. 結果および考察}

(1)基本的なプロフィール

(1)調查対象の基本的な属性

調査対象の基本的な属性については，マニア 群とビギナー群で大きな差異はみられなかった
(Table.2〜Table.7).有意差は認められなかっ たが，やや差異が見られた項目として，マニア 群のほうが年齢層が高い傾向と既婚率が高い傾 向，また，ビギナー群のほうが 1 力月の自由裁 量所得 (小遣い) がやや多い傾向，がみられた。

Table.2 性別

\begin{tabular}{|c|c|c|}
\hline & マニア群 & ビギナー群 \\
\hline 男 性 & 63 & 35 \\
\hline 女 性 & $62.4 \%$ & $60.3 \%$ \\
\hline 計 & $37.6 \%$ & 23 \\
\hline
\end{tabular}

Table.3 年齢

\begin{tabular}{|c|c|c|}
\hline & マニア群 & ビギナー群 \\
\hline \multirow{2}{*}{$18-19$ 歳 } & 3 & 4 \\
& $3.0 \%$ & $6.9 \%$ \\
\hline $20-29$ 歳 & 28 & 23 \\
& $27.7 \%$ & $39.7 \%$ \\
\hline $30-39$ 歳 & $19.8 \%$ & 14 \\
\multirow{2}{*}{$40-49$ 墄 } & $28.7 \%$ & $7 \%$ \\
\hline $50-59$ 墄 & $17.8 \%$ & $12.1 \%$ \\
\hline \multirow{2}{*}{60 歳以上 } & $4.0 \%$ & $15.5 \%$ \\
\hline 計 & 101 & $1.7 \%$ \\
\hline
\end{tabular}

Table.4 結婚の有無

\begin{tabular}{|c|c|c|}
\hline & マニア群 & ビギナー群 \\
\hline 未 婚 & 30 & 27 \\
既 婚 & $29.7 \%$ & $46.6 \%$ \\
\hline 計 & 71 & 31 \\
\hline
\end{tabular}

Table.5 職業

\begin{tabular}{|c|c|c|}
\hline & マニア群 & ビギナー群 \\
\hline 自 営 業 & $\begin{array}{c}11 \\
10.9 \% \\
\end{array}$ & $\begin{array}{c}8 \\
13.8 \% \\
\end{array}$ \\
\hline 家族従業 & $\begin{array}{c}2 \\
2.0 \%\end{array}$ & $\begin{array}{c}0 \\
0.0 \%\end{array}$ \\
\hline 会社役員 & $\begin{array}{c}18 \\
17.8 \% \\
\end{array}$ & $\begin{array}{c}6 \\
10.3 \% \\
\end{array}$ \\
\hline 勤 め人 & $\begin{array}{c}44 \\
43.6 \% \\
\end{array}$ & $\begin{array}{c}30 \\
51.7 \% \\
\end{array}$ \\
\hline 学 生 & $\begin{array}{c}11 \\
10.9 \%\end{array}$ & $\begin{array}{c}8 \\
13.8 \% \\
\end{array}$ \\
\hline 主＼cjkstart婦 & $\begin{array}{c}11 \\
10.9 \% \\
\end{array}$ & $\begin{array}{c}4 \\
6.9 \% \\
\end{array}$ \\
\hline その 他 & $\begin{array}{c}4 \\
4.0 \% \\
\end{array}$ & $\begin{array}{c}2 \\
3.4 \% \\
\end{array}$ \\
\hline 計 & 101 & 58 \\
\hline
\end{tabular}


Table.6 家族全体の収入

\begin{tabular}{|c|c|c|}
\hline & マニア群 & ビギナー群 \\
\hline $\begin{array}{l}300 \text { 万円 } \\
\text { 未満 }\end{array}$ & $\begin{array}{c}7 \\
7.0 \% \\
\end{array}$ & $\begin{array}{l}3 \\
5.1 \% \\
\end{array}$ \\
\hline $\begin{array}{l}\text { 300-500 } \\
\text { 万円未満 }\end{array}$ & $\begin{array}{c}17 \\
16.8 \% \\
\end{array}$ & $\begin{array}{c}8 \\
13.7 \% \\
\end{array}$ \\
\hline $\begin{array}{l}\text { 500-700 } \\
\text { 万円未満 }\end{array}$ & $\begin{array}{c}20 \\
19.8 \% \\
\end{array}$ & $\begin{array}{c}13 \\
22.4 \% \\
\end{array}$ \\
\hline $\begin{array}{l}700-1000 \\
\text { 万円未満 }\end{array}$ & $\begin{array}{c}21 \\
20.8 \% \\
\end{array}$ & $\begin{array}{c}12 \\
20.7 \% \\
\end{array}$ \\
\hline $\begin{array}{l}1000 \\
\text { 万円以上 }\end{array}$ & $\begin{array}{c}26 \\
25.8 \% \\
\end{array}$ & $\begin{array}{c}13 \\
22.4 \% \\
\end{array}$ \\
\hline 無回答 & $\begin{array}{c}10 \\
9.9 \% \\
\end{array}$ & $15.5 \%$ \\
\hline 計 & 101 & 58 \\
\hline
\end{tabular}

Table.7一ヶ月の自由裁量所得 (小遣い)

\begin{tabular}{|c|c|c|}
\hline & マニア群 & ビギナー群 \\
\hline 2 万円未満 & 20 & 11 \\
\hline 2 万円〜 & $19.8 \%$ & $18.9 \%$ \\
\hline 3 万円未満 & 21 & 8 \\
\hline 3 万円〜 & $20.8 \%$ & $13.8 \%$ \\
\hline 5 万円未満 & $30.7 \%$ & 17 \\
\hline 5 万円〜 & 21 & $29.3 \%$ \\
10 万円未満 & $20.8 \%$ & 16 \\
\hline 10 万円以上 & $6.9 \%$ & $27.6 \%$ \\
\hline 無回答 & 2 & $6.9 \%$ \\
\hline 計 & $2.0 \%$ & 2 \\
\hline
\end{tabular}

\section{(2)現在のスポーツ実施頻度}

現在のスポーツの実施頻度は，「月10日以上」 が $10.5 \%$,「月 4 日以上」が $38.9 \%$ ，「月 2 日 3 日 が36.5\%，「月 1 日以下」が14.1\%，という分布 であり，ほぼわが国における標準的なスポーツ 実施頻度に近いサンプルであった。. ${ }^{13)}$

(3)過去のスポーツの傾倒度

全体の傾向はマニア群の傾向に近く, 学校期 が進むにつれて「かなり熱心に行った」とする 比率が増えていく.（Fig.4）

また，マニア群においては,「かなり熱心に行 った」と「熱心に行った」というサンプルがす べての学校期（小・中・高・大）を通じて 8 割 以上を占めるのに対し, ビギナー群では, 小学 校期と高校期にそれが 6 割程度, 中学期は 5 割, 大学期は 4 割程度になっていた。（Fig.5, Fig.6)

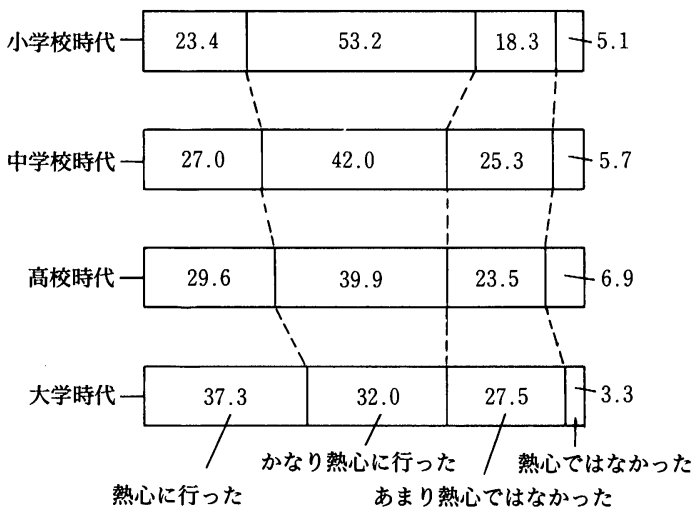

Fig.4 過去のスポーツの系統度（全体）

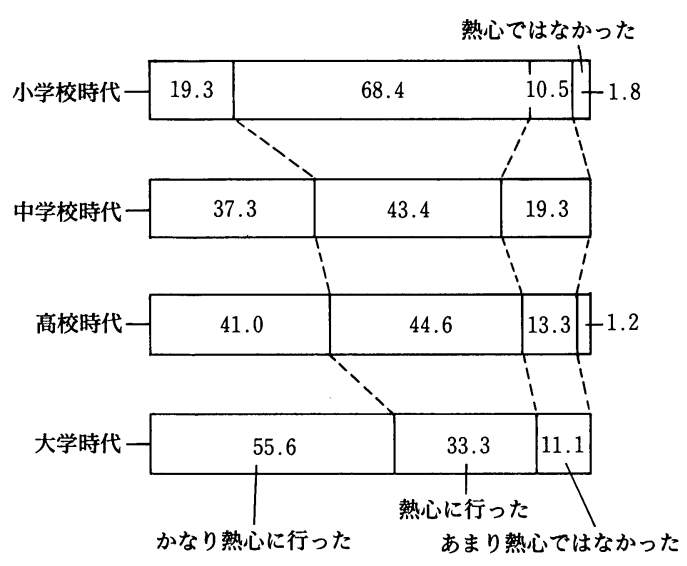

Fig.5 過去のスポーツの傾倒度（マニア群）

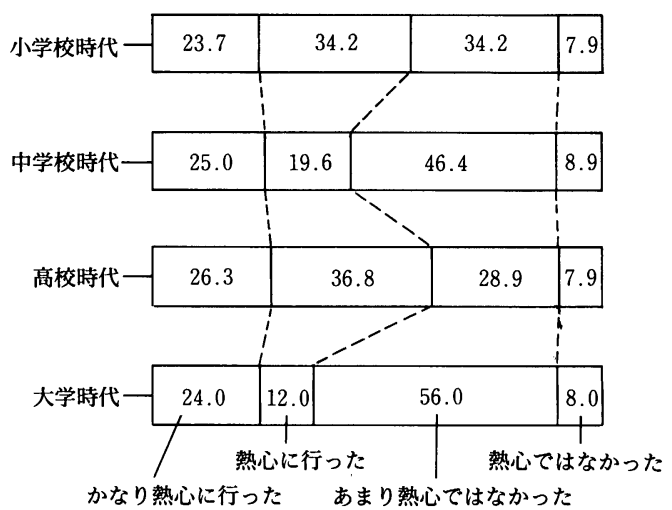

Fig.6 過去のスポーツの傾倒度（ビギナー群） 
Table.8 スポーツサービス業におけるプロダクトの各層へのニーズ

\begin{tabular}{|l|c|c|c|}
\hline & $\begin{array}{c}\text { マニア群 } \\
\operatorname{MEAN}(\text { S.D. })\end{array}$ & $\begin{array}{c}\text { ビギナー群 } \\
\text { MEAN(S.D.) }\end{array}$ & $\mathrm{t}$ 検定 \\
\hline 拡延的プロダクト & $3.38(2.79)$ & $3.38(3.03)$ & 0.01 \\
\hline 構造的プロダクト & $4.48(3.05)$ & $5.02(3.04)$ & 1.06 \\
\hline 中核的プロダクト(手段的機能) & $4.68(2.79)$ & $3.60(2.96)$ & $2.28 *$ \\
\hline 中核的プロダクト(目的的機能) & $2.24(2.76)$ & $1.41(2.49)$ & $1.93 *$ \\
\hline
\end{tabular}

$\mathrm{t}$ 検定 $* \mathrm{P}<0.05$

$* * \mathrm{P}<0.01$
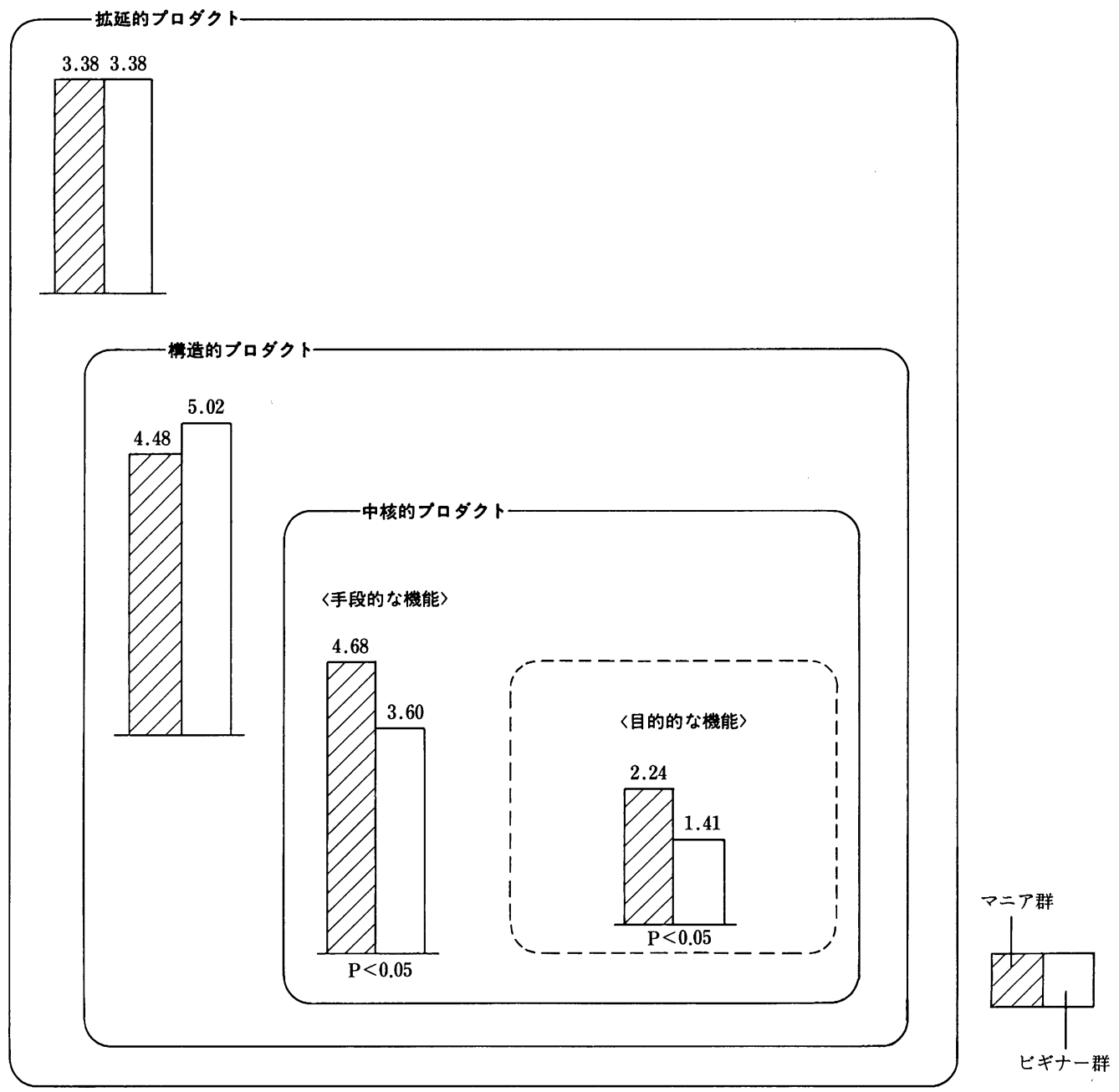

Fig.7 スポーッ施設サービス業におけるプロダクトの各層へのニーズ

(2)スポーツサービス業のプロダクトへのニーズ

(1)拡延的プロダクト

合成変数からみた拡延的プロダクトへのニー ズは（注 6 ), マニア群とビギナー群でニーズの 高さに差異は認められなかった. (Table.8,Fig.7)
各構成項目（注 7 ）でみると，「スポーツ以外 の文化活動が楽しめる」食堂やレストランなど がある」といった項目で，マニア群のニーズが 高かった. (Table.9) 
Table.9 拡延的プロダクトへのニーズ

\begin{tabular}{|l|l|c|c|c|}
\hline & & $\begin{array}{c}\text { マニア群 } \\
\mathrm{N}=95\end{array}$ & $\begin{array}{c}\text { ビギナー群 } \\
\mathrm{N}=51\end{array}$ & $\chi^{2}$ 值 \\
\hline \multirow{3}{*}{ アメニティー } & くつろげるスペースや施設がある & $47(52.8 \%)$ & $28(52.8 \%)$ & 0.00 \\
& おしゃれな需囲気がある & $28(31.5 \%)$ & $15(28.3 \%)$ & 0.16 \\
& 個人でも入りやすい雲囲気がある & $48(53.9 \%)$ & $29(54.7 \%)$ & 0.01 \\
& 水や緑が豊富である & $38(42.7 \%)$ & $22(41.5 \%)$ & 0.02 \\
\hline 付帯的エリアサービス & 食堂やレストランなどがある & $49(55.1 \%)$ & $25(47.2 \%)$ & 0.83 \\
& 託児室などの子どもを預かる施設がある & $27(30.3 \%)$ & $17(32.1 \%)$ & 0.05 \\
\hline 他の文化との融合 & スポーツ以外の文化活動が楽じめる & $25(28.1 \%)$ & $12(22.6 \%)$ & 0.51 \\
& 美しい絵や音楽が楽しめる & $18(20.2 \%)$ & $11(20.8 \%)$ & 0.01 \\
& スポーツ以外の文化活動の成果を発表できる & $13(14.6 \%)$ & $7(13.2 \%)$ & 0.05 \\
\hline 接客 & 指導者以外の職員の態度やサービスがよい & $48(53.9 \%)$ & $30(56.6 \%)$ & 0.10 \\
\hline
\end{tabular}

Table.10 構造的プロダクトへのニーズ

\begin{tabular}{|c|c|c|c|c|}
\hline & & $\begin{array}{c}\text { マニア群 } \\
\mathrm{N}=95\end{array}$ & $\begin{array}{c}\text { ビギナー群 } \\
\mathrm{N}=51\end{array}$ & $\chi^{2}$ 值 \\
\hline エリアサービス & $\begin{array}{l}\text { 施設全体が清潔に保たれている } \\
\text { 安全面への配慮が行き届いている } \\
\text { いつもすいていて使いやすい } \\
\text { 利用方法・手続きが簡単である } \\
\text { 朝早くから夜遅くまで利用できる } \\
\text { 個人利用の時間帯が十分にある } \\
\text { シャワーの温水化など快適性への配慮がある } \\
\text { どんな活動ができるのかがよくわかる } \\
\text { スポーツ事故等への補償が充実している } \\
\end{array}$ & $\begin{array}{l}65(73.0 \%) \\
62(69.7 \%) \\
54(60.7 \%) \\
62(69.7 \%) \\
51(57.3 \%) \\
48(53.9 \%) \\
50(56.2 \%) \\
32(36.0 \%) \\
36(40.4 \%)\end{array}$ & $\begin{array}{l}41(77.4 \%) \\
36(67.9 \%) \\
42(79.2 \%) \\
37(69.8 \%) \\
35(66.0 \%) \\
32(60.4 \%) \\
37(69.8 \%) \\
17(32.1 \%) \\
25(47.2 \%)\end{array}$ & $\begin{array}{l}0.33 \\
0.05 \\
5.23 * \\
0.00 \\
1.06 \\
0.56 \\
2.60 \\
0.22 \\
0.61\end{array}$ \\
\hline プログラムサービス & $\begin{array}{l}\text { 必要に応じて健康相談・チェックが受けられる } \\
\text { やりたい活動が出来る } \\
\text { 豊富なプログラムがある } \\
\text { 必要なときに指導者のアドバイスを受けられる } \\
\text { 子どもから高齢者まで楽しめる }\end{array}$ & $\begin{array}{l}43(48.3 \%) \\
35(39.3 \%) \\
27(30.3 \%) \\
40(44.9 \%) \\
34(38.2 \%)\end{array}$ & $\begin{array}{l}22(41.5 \%) \\
26(49.1 \%) \\
23(43.4 \%) \\
26(49.1 \%) \\
26(49.1 \%)\end{array}$ & $\begin{array}{l}0.62 \\
1.28 \\
2.48 \\
0.23 \\
1.60\end{array}$ \\
\hline 指導者 & $\begin{array}{l}\text { 指導者の指導能力が優れている } \\
\text { 指導者が量的に充実している } \\
\text { アルバイトの指導者が少ない } \\
\text { 指導者の態度やマナーがよい }\end{array}$ & $\begin{array}{l}48(53.9 \%) \\
31(34.8 \%) \\
12(13.5 \%) \\
48(53.9 \%)\end{array}$ & $\begin{array}{l}23(43.4 \%) \\
17(32.1 \%) \\
13(24.5 \%) \\
25(47.2 \%)\end{array}$ & $\begin{array}{l}1.48 \\
0.11 \\
2.79 \\
0.61\end{array}$ \\
\hline $\begin{array}{l}\text { 立地・アクセス・ } \\
\text { 利用料金 }\end{array}$ & $\begin{array}{l}\text { 立地条件が行きやすい場所にある } \\
\text { 駐車場が十分, 確保されている } \\
\text { 利用料金が手軽である }\end{array}$ & $\begin{array}{l}64(71.9 \%) \\
64(71.9 \%) \\
67(75.3 \%)\end{array}$ & $\begin{array}{l}44(83.0 \%) \\
38(71.7 \%) \\
44(83.0 \%)\end{array}$ & $\begin{array}{l}2.25 \\
0.00 \\
1.17\end{array}$ \\
\hline する以外のスポーツ & スポーツに関する文献や書物を閲覧できる & $23(25.8 \%)$ & $11(20.8 \%)$ & 0.47 \\
\hline
\end{tabular}

概して上記項目は，直接にスポーツに結合し ないという拡延的プロダクトの中でも, 比較的, スポーツ施設サービスの必要条件に近い項目と
考えられる。

(2)構造的プロダクト

合成変数からみた構造的プロダクトへのニー 
ズは，概してビギナー群のほうがマニア群より も高かったが, 統計的に有意な差はみられなか った.（Teble.8,Fig.7）

各構成項目 (注 7 ) でみると,「シャワーの温 水化など快適性への配慮がある」いつもすいて いて使いやすい」「朝早くから夜遅くまで利用で きる」スポーツ事故等への補償が充実している」 といったエリアサービスに関する項目と「子ど もから高齢者まで楽しめる」やりたい活動が出 来る」「豊富なプログラムがある」などのプログ ラムサービスに関する項目，また「アルバイト の指導者が少ない」といった指導体制に関する 項目，立地条件や利用料金に関する項目でビギ ナー群がマニア群よりも高いニーズを示してい た.一方，「指導者の指導能力が優れている」指
導者の態度やマナーがよい」といった指導者の 質に関する項目は，マニア群のほうが高いニー ズがあった。（Table.10）

(3)中核的プロダクト

合成変数からみた中核的プロダクトへのニー ズは,手段論的な側面と目的論的な側面で把握し たが,どちらにおいても,マニア群のほうが有意 に高いニーズを示していた。（Table.8,Fig.7）

各構成項目（注 8 ）でみると手段的な側面で は「体力の保持・増進が出来る」「健康の保持・増 進が出来る」といった生理的欲求に関する項目 で,目的論的な側面では「相手との競争を楽しむ」 「生きがいを感じる」工夫する楽しさを味わう」 といった自己実現的欲求に関する項目で,マニア 群が高いニーズを示していた。（Table.11）

Table.11 中核的プロダクトへのニーズ

\begin{tabular}{|c|c|c|c|c|}
\hline . & , & $\begin{array}{c}\text { マニア群 } \\
\mathrm{N}=95\end{array}$ & $\begin{array}{c}\text { ビギナー群 } \\
N=51\end{array}$ & $\chi^{2 \text { 值 }}$ \\
\hline 手段的な機能 & $\begin{array}{l}\text { 健康の維持・増進できる } \\
\text { 体力の保持・増進できる } \\
\text { ストレスを解消できる } \\
\text { 気分転換ができる } \\
\text { 友人と交流できる } \\
\text { "つきあい" を行える } \\
\text { 流行に沿える }\end{array}$ & $\begin{array}{l}65(68.4 \%) \\
65(68.4 \%) \\
55(57.9 \%) \\
58(61.1 \%) \\
53(55.8 \%) \\
24(25.3 \%) \\
11(11.6 \%)\end{array}$ & $\begin{array}{l}25(49.0 \%) \\
19(37.3 \%) \\
25(49.0 \%) \\
30(58.8 \%) \\
27(52.9 \%) \\
11(21.6 \%) \\
9(17.6 \%)\end{array}$ & $\begin{array}{c}5.28 * \\
13.19 * * \\
1.06 \\
0.07 \\
0.11 \\
0.25 \\
1.03\end{array}$ \\
\hline 目的的な機能 & $\begin{array}{l}\text { 工夫する楽しさを味わうことができる } \\
\text { 生きがいを感じることができる } \\
\text { ゆりを感じることができる } \\
\text { 相手との競争を楽しむことができる } \\
\text { 自然に挑戦することができる }\end{array}$ & $\begin{array}{l}21(22.1 \%) \\
28(29.5 \%) \\
23(24.2 \%) \\
28(29.5 \%) \\
13(13.7 \%)\end{array}$ & $\begin{array}{l}8(15.7 \%) \\
8(15.7 \%) \\
12(3.5 \%) \\
8(15.7 \%) \\
5(9.8 \%)\end{array}$ & $\begin{array}{l}0.86 \\
3.40 \\
0.01 \\
3.40 \\
0.46\end{array}$ \\
\hline
\end{tabular}

以上の結果からは, 拡延的プロダクト層にお いては，必要条件に近い項目でマニア群が，構 造的プロダクト層においては，プログラムサー ビスとエリアサービスでビギナー群が，指導者 の質でマニア群が，中核的プロダクト層ではマ ニア群が,他群に比べ高いニーズを有していた。

また,各層ごとに各構成項目を集約しスコアー 化した分析からは, マニア群が「三層均衡型ニー ズ」,ビギナー群が「中核軽視型ニーズ」といっ た様相を呈していたといえる. (Table.8,Fig.7)

\section{IV. 総括}

本研究は, P.Kotlerのプロダクトの中核思想 を参考にしながら，スポーツ施設サービス業に おけるプロダクトの構造について検討した。

そして，利用者のスポーツの享受レベルの向 上と求められるプロダクト構成の変容の関係に 着目し，あるべきスポーツサービス業のプロダ クト，あるべきスポーツサービスについて検討 した. 
そして，利用者の享受レベルと求められるプ ロダクトの構成の関係について，以下のような 結果が得られた。

1 ) 中核的プロダクトについては，マニア群の ほうが，ビギナー群に比へ，有意に高いニ ーズを持っていた。

2 ）構造的プロダクト，拡延的プロダクトにつ いては，両群に有意なニーズの差はみられ なかった。

概していえば，プロダクトの三層へのニーズ からは，マニア群は「三層均衡型」なのに対し， ビギナー群は「中核軽視型」のニーズの様相を 示していたといえる.

尚，ビギナー群とマニア群を比較したバック ワード的な分析の結果からは，両群に特徵的な 有意な差異はみられなかった。このことから， プロダクトへのニーズと享受レベルの関係が強 いことが類推された。

また，プロダクトの各層の各構成項目につい ては，以下のような特徵がみられた。

1) 拡延的プロダクトの層では, 直接にスポー ツに結合しないという拡延的プロダクトの 中でも，比較的，スポーツ施設サービスの 必要条件に近い項目においてマニア群のニ ーズが高い傾向がみられた。

2 )構造的プロダクトの層では，マニア群が「指 導者の質」へのニーズが高い一方で，ビギ ナー群が「プログラムサービス」や「エリ アサービス」へのニーズが高い傾向がみら れた。

3 ）中核的プロダクトの層では，手段的機能と 目的的機能のどちらにおいても，マニア群 のニーズが高い傾向がみられたが，手段的 機能では「健康・体力志向」, 目的的機能で は「競争する楽しみ」「夫する楽しみ」「生 きがい的な楽しみ」といった項目で特にマ ニア群のニーズが高い傾向がみられた。

以上の結果からは，スポーツとの付き合いが 深まるにつれて，その本質的な魅力を理解して いく過程が示唆され，こうしたニーズの変容を 見越したプロダクトを提示するためには，その
コアへ導くサービスが重要になると考えられた。

つまり，ビギナーのニーズに迎合して，コア 以外の部分に力をいれても，ビギナーがマニア になる過程で「ホンモノに気づいたとき」離れ ていくのでは，永続的な発展は望めないし，ま た, 本当のスポーツの楽しみに気づかなければ, その取り組みは深くはならず，利用者の離脱を 招く結果となることが予想できるのである.

利用者は多様なニーズをもって，スポーツ施 設サービス業にアクセスする。それは，コアの 部分へのニーズかもしれないし，コア以外への それかもしれない，多くは，その両者に関わる ものであろうが，上述のように，そこでのサー ビスの本質は，その中核的な部分の便益を十分 に味わってもらい, スポーツの意味や価值の理 解を深めてもらうことである，その意味でスポ ーツサービスとは，あくまでも能力開発型のサ 一ビスであるべきで，行う者の主体的な取り組 みによって自らの変化や達成感, 充足感を感じ ることが出来たときに初めて，そのサービスは 評価されるということがスポーツサービスの特 性であると考えられる。

享受の仕方がスポーツ産業の将来の鍵をにぎ る，という視点からは，このスポーツ施設サー ビス業におけるスポーツサービスは重要な意味 をもってくる．特に，直接的なインストラクシ ヨンに関わるサービスの分野は重要である，イ ンストラクターが上述のようなスポーツサービ スの本質を忘れ，快適さや格好の良さばかりを 追求し，スポーツの本質的価值を伝えずに気の きいた会話や安易な楽しみを与えるサービス者 となってしまうならば，その活動は「インスト ラクション」ではなく「接客」になってしまう。 そして，それはスポーツの表面的な価值しかし らないスポーツ享受者を大量に作りだすことに なり,結局は本質的価值を知らないこれらの人々 はスポーツに飽きたらまた次の流行へと流れて しまうかもしれない.

特に今回の結果からは，ビギナー群には，P． Kotlerのいう可視的なプロダクトへのニーズは 高く，とりわけエリアサービスとプログラムサ 
ービスへのニーズが高い傾向があることから， これらのニーズの充足を出発点に，ビギナーの 持つプログラムサービスへの高いニーズをうま くプロダクトに組み込み，スポーツの本質的な 楽しさに気づくことへのサポートをすることが 重要である。

また，マニア群に関しては，その拡延的プロ ダクトへのニーズから「必要条件としての拡延

\section{参考・引用文献}

1）深瀬吉邦・牧川優，「商業スポーツ施設事業における 商品論」（社）日本スイミングクラブ協会・(社）日 本プロテニス協会・(社) 日本プロゴルフ協会・(財) 日本スポーツクラブ協会・(財) 日本健康スポーツ連 盟(編), C 級教師教本サービス論, 上記五団体発行, 1990,pp.15-26

2 ) 平川澄子・仲澤眞「コマーシャルスポーツにおける 指導者とその役割」(財)日本体育協会(編), C 級教師 教本，財水日本体育協会, 1990,pp.66-73.

3 ）飯島義郎, 現代商品学の方法, 文真堂, 1982,p169.

4) 前掲書 3 ) pp.173-74.

5 ）北原三郎「製品開発と商品学の役割」ビジネスレビ ュー, 17-1,1969.

6）橘川真彦・加賀秀夫 ・小林一彦「体育授業における 楽しさに関する調査研究」辰野・福沢 (編), 教科学 習の心理学, 図書文化, 1987,pp.203-13.

7 ）仲澤眞「日本のスポーツ市場ースポーツ産業論の視 点から」Japanese Journal of Sports Sciences, 10 $-4: 253-57,1991$.

8 ）西順一・橘川真彦「体育授業における運動の楽しさ の実態及び生涯スポーツとの関連」体育社会学研究 会 (編), 体育社会学研究 9, 道和書院, 1980.pp.41 $-62$.

9) フィリップ・コトラー（小坂怒・正田聰・三村優美 子訳)，マーケティング・マネジメント，第 4 版，プ レジデント社, 1983,Pp526. (Philip Kotler, Marketing Management, Prentice-Hall, Inc. 1980)

10）前揭書 9）pp.305-07.

11）佐伯聰夫，スポーツ産業の概念，スポーツ教育筑波 国際研究集会資料，1990.

12）佐伯聰夫「スポーツの文化的内容」勝部篤・条野豊 (編), コーチのためのスポーツ人間学, 大修館書店, 1983.pp.221-25.

13）総務庁統計局（編）, 社会生活基本調查報告， 1986.

14）スポーツ産業研究会ワーキンググループ，スポーツ 施設経営・サービスの現状と課題, スポーツ産業研 究会討議資料, 1990 .

15）前掲14）
的プロダクト」への知見を得ることも重要であ ると考えられる，さらにマニア群には，健康・ 体力志向の項目で手段的なニーズが顕著に高か ったが，手段的な効用も実感しながらも，そう した功利を超えた楽しみを味わってもらうこと も大切である，それが，さらに高いスポーツの 享受レベルを実現するのであろう。

16）通商産業省産業政策局編，スポーツビジョン 21 スポーツ産業研究会報告書, 財団法人通商産業調査 会, $1990, p p .49-57$.

17）上坂西三, 商品学概論, 1926.pp.3-5.

18）柳沢和雄「日本における体育・スポーツ経営学研究 の動向」体育・スポーツ経営学研究, 6-1:52-54. 1989.

19）柳沢和雄「体育・スポーツ事業論の課題」日本体育 学会第41回大会体育経営管理専門分科会シンポジウ 么資料, 1990.

20）柳沢和雄「商業スポーツ施設事業における商品の三 層構造」商業スポーツ経営研究会討議資料, 1989.

21）八代勉・柳沢和雄「ユーザー離脱のメカニズム/離 脱の構造」月刊スポーツインダストリー, 6-2:1214,1991 .

22）吉田富義，現代商品論，同友館，1988.pp.39-60.

23）財団法人余暇開発センター, レジャー白書' 90 , 財団 法人余服開発センター, 1990,p.58.

注 1 ） 本データは, 東京都が実施し, 仲澤眞・平川澄子 (鶴見大学) ・柳沢和雄 (筑波大学) 調査研究協力 した「都民のスポーツ活動に関する現状調查報告 書」東京都生活文化局, 1990.Pp.192.で得たデー夕 である.

注 2 ） 欠票内訳：転居12(1.2\%)長期不在 $15(1.5 \%)$ 一時 不在62(6.2\%)住所不明15(1.5\%)拒否98(9.8\%) その他 $2(0.2 \%)$

注 3 ) 先行研究では, 生理的欲求として健康欲求, 活動 欲求, 解放欲求, 安全欲求が, 社会的欲求として 所属欲求, 協同欲求, 承認欲求が, 自己実現的欲 求として遊戯欲求, 競争欲求, 達成欲求, 探索欲 求, 表現欲求, 創造欲求が挙げられていたが, 本 研究ではスポーツ施設サービス業におけるスポー ツに限定し, 項目を抽出した。

注 4 ) Fig.3は，クラブ・サービスの項目が盛り込まれて いるが，スポーツ施設サービス業の現状では，ス ポーツ集団を育成するサービスはあまり一般的で はないので,その項目を調査項目から省いている. 
尚, クラブサービスを広義におさえれば, Fig.3の サービスすべてを意味するが, ここで調査から省 いたクラブサービスはいわゆるエリア, プログラ ムとならび称されるクラブ・サービスである. また，拡延的プロダクトにある記号的な意味の 内容については, 調査対象が広範にわたり, まっ たく民間のスポーツ・サービスに参与しない対象 も多く含まれたため, 調査項目からは削除した。

注 5 ）具体的には, 「現在, 月に 4 日以上スポーツ活動を 行う」と回答したサンプルの中から, 小・中・高・ 大のいずれかの学校期にスポーツを「かなり熱心 に行った」または「熱心に行った」と回答したも のを享受レベルの高いサンプル＝「マニア群」と して, 一方, 現在の頻度が「月に 3 日以下」と回 答したサンプルの中から, 小・中・高・大のいず れかの学校期にスポーツには「あまり熱心ではな
かった」「熱心ではなかったっと回答したものを享 受レベルの低いサンプル＝「ビギナー群」として 扱った。

注 6 ) Table.8ならびにFig.7は, Table.9〜Table.11にあ るすべての項目を等しいウェイトで合成し, 満点 を10として標準化したスコアである.

注 7 ) Table.9〜 Table.10は, 商品の各層の構成項目とし て挙げられた項目に，「望む」と「望まない」のう ち「望む」と回答した各群のサンプルの実数と各 群に占める割合を百分比で示したものである.

注 8 ) Table.11は, 中核的商品の構成項目として挙げら れた項目に「目的とする」「目的としない」のう ち「目的とする」と回答した各群のサンプルの実 数と各群に占める割合を百分比で示したものであ る. 